Article

\title{
Experimental Study of a Small-Size Vacuum Insulated Water Tank for Building Applications
}

\author{
David Vérez ${ }^{1}$, Emiliano Borri ${ }^{1}{ }^{(\mathbb{C}}$, Alicia Crespo ${ }^{1}$, Gabriel Zsembinszki $\left.{ }^{1}{ }^{(}\right)$, Belal Dawoud ${ }^{2}(\mathbb{D}$ \\ and Luisa F. Cabeza ${ }^{1, *(D)}$ \\ 1 GREiA Research Group, Universitat de Lleida, 25001 Lleida, Spain; david.verez@udl.cat (D.V.); \\ emiliano.borri@udl.cat (E.B.); alicia.crespo@udl.cat (A.C.); gabriel.zsembinszki@udl.cat (G.Z.) \\ 2 Laboratory of Sorption Processes, Faculty of Mechanical Engineering, East Bavarian Technical University of \\ Applied Sciences (OTH-Regensburg), 93053 Regensburg, Germany; belal.dawoud@oth-regensburg.de \\ * Correspondence: luisaf.cabeza@udl.cat; Tel.: +34-973-003-576
}

Citation: Vérez, D.; Borri, E.; Crespo, A.; Zsembinszki, G.; Dawoud, B.;

Cabeza, L.F. Experimental Study of a Small-Size Vacuum Insulated Water Tank for Building Applications. Sustainability 2021, 13, 5329. https:// doi.org/10.3390/su13105329

Academic Editor: Miguel Ángel Reyes Belmonte

Received: 14 March 2021

Accepted: 8 May 2021

Published: 11 May 2021

Publisher's Note: MDPI stays neutral with regard to jurisdictional claims in published maps and institutional affiliations.

Copyright: (c) 2021 by the authors. Licensee MDPI, Basel, Switzerland. This article is an open access article distributed under the terms and conditions of the Creative Commons Attribution (CC BY) license (https:/ / creativecommons.org/licenses/by/ $4.0 /)$.

\begin{abstract}
Insulation of thermal energy storage tanks is fundamental to reduce heat losses and to achieve high energy storage efficiency. Although water tanks were extensively studied in the literature, the enhancement of the insulation quality is often overlooked. The use of vacuum insulation has the potential to significantly reduce heat losses without affecting the dimension of the storage system. This paper shows for the first time the results of the heat losses tests done for a $0.535 \mathrm{~m}^{3}$ water tank for residential building applications built with a double wall vacuum insulation. The different tests show that the rate of heat losses strictly depends on the temperature distribution inside the tank at the beginning of the experiment. Compared to a conventional water tank insulated with conventional materials, the U-value of the lateral surface was reduced by almost three times (from $1.05 \mathrm{~W} / \mathrm{K} \cdot \mathrm{m}^{2}$ to $0.38 \mathrm{~W} / \mathrm{K} \cdot \mathrm{m}^{2}$ ) using vacuum insulation. However, the bottom part, which is usually used to place the support parts and the piping, is the critical design part of those tanks acting as a thermal bridge with the ambient and enhancing heat losses.
\end{abstract}

Keywords: thermal energy storage; water tank; thermal insulation; vacuum insulation; heat losses test; building applications

\section{Introduction}

The use of renewable energy sources is one of the key actions towards the reduction of gas emissions into the atmosphere. Today, the exploitation of solar energy in building applications represents the most common alternative to the use of fossil fuels to supply thermal energy for space heating or domestic heat water. However, due to the mismatch between solar availability and energy demand, the integration of thermal energy storage (TES) is fundamental to enhance the efficiency of solar heating systems increasing the potential use of renewable energy resources [1,2]. TES applied to solar heating systems allows to store thermal energy when it is highly available and release it when solar radiation is low and energy demand is needed. In solar heat applications with temperatures below $100{ }^{\circ} \mathrm{C}$, water represents the most common storage material due to the high specific heat, low cost, and availability. In this case, TES commonly refers to water tanks. This storage typology was studied in the literature for decades. In order to evaluate the topics that had the highest relevance in the scientific literature, bibliometric analysis is an effective method to evaluate research trends and gaps [3-5]. Figure 1 shows the co-occurrence of the keywords used by the authors on a total number of 2006 studies published in the literature related to water storage tanks. Documents were obtained from the Scopus database on April 2021 using the query "TITLE-ABS-KEY ("water tank" AND "storage") and analysed through the software VOSviewer [6]. The results show that studies on water tanks are mainly related to "stratification". Indeed, the efficiency of water tanks can be enhanced by exploiting the stratification effect that naturally takes place due to the difference in density 
induced by the water at different temperatures. This allows to extract hot water at the top (that can be used for domestic hot water) and less heated water in the middle (that can be suitable for space heating). In the literature, different studies and techniques were proposed to improve the stratification by enhancing the stratification effect [7-12]. Other studies were related to the integration of phase change materials (PCM) to increase the storing efficiency $[13,14]$ and the use of water tanks with heat pumps using demand-side management techniques [15-17]. Furthermore, the figure shows that most of the studies were conducted through simulations, highlighting a lack of experimental studies.

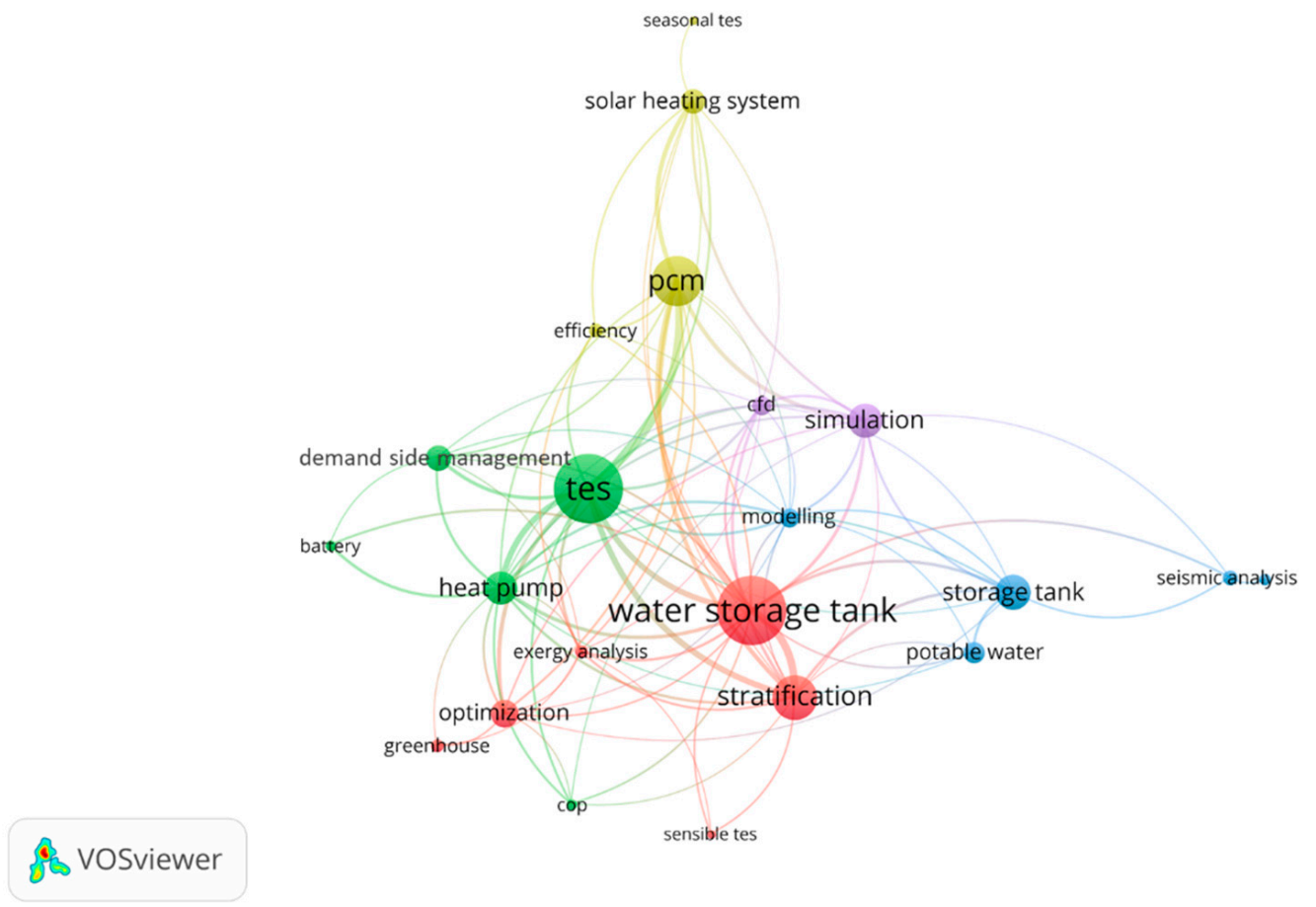

Figure 1. Co-occurrence of the authors keywords in studies related to water tanks.

In the co-occurrence of authors keywords, it is possible to notice that there are no terms related to heat losses and/or insulation. When water storage tanks are integrated into systems where the thermal energy is managed in a short-term period, the weight of heat losses on the global performance is lower compared to the quality of stratification that affects the temperature delivered by the tank.

However, today the attention is moving to thermal energy storage solutions able to manage and store thermal energy for long or seasonal periods, allowing a better use of energy coming from renewable sources. Therefore, the need for storage systems with reduced heat losses is fundamental. To achieve this, many studies in the literature focus on new emerging technologies such as thermochemical TES and only a few are based on the improvement of existing and commercially available technologies. For this reason, thermal insulation represents a significant aspect in the optimisation of commercial TES systems. Furthermore, in water tanks, the reduction of heat losses helps to maintain the stratification, thus increasing the exergy efficiency of the tank [18]. Practically, thermal insulation can be placed either inside or outside the storage system. However, placing the insulation outside is usually the simplest option. At present, most water tank storage systems are insulated using conventional materials such as mineral wool with thermal conductivity in the range of 19 to $46 \mathrm{~mW} /(\mathrm{m} \cdot \mathrm{K})$ [19]. Therefore, to significantly achieve low heat losses with conventional materials, thicker insulation is required to increase the living space of the storage and, indirectly, the cost. 
Using vacuum insulation, the thermal conductivity can be reduced 6 to 10 times compared to conventional materials [20]. Those type of tanks are already used to store cryogenic materials such as liquefied nitrogen, air, or natural gas (LNG) [21,22].

Recently, vacuum insulation is also used in water tanks for solar heating applications to store water below $90^{\circ} \mathrm{C}$. However, only a few studies were published in the literature. The benefit of using a vacuum insulated storage tank in solar systems for a multi-family house located in Estonia was studied by Kadler et al. [23]. The results showed that using a vacuum insulated water tank to store the solar heat on a seasonal basis increases the direct renewable heating by $41 \%$, reaching a system efficiency of $51 \%$. Vacuum insulation can be integrated mainly into a storage tank through the use of vacuum insulation panels (VIPs) or realising a double wall vacuum envelope (done through evacuated powders) $[19,24]$. The testing of a $100 \mathrm{~m}^{3}$ water storage tank using VIPs was reported in the literature by Fuchs [25]. The water tank used in [16], which was built in Sengenthal (Germany), consisted of eight precast concrete elements with VIP attached inside the storage. Heat losses tests were performed for 31 days; results gave a U-value of $0.36 \mathrm{~W} /\left(\mathrm{m}^{2} \cdot \mathrm{K}\right)$. This value corresponds to only $30 \%$ of the one estimated from the initial calculations due to thermal bridges and defects on the insulation. Regarding water storage with double wall, a water tank of $16.4 \mathrm{~m}^{3}$ with a 20 -cm-thick insulation of evacuated perlite was built at the Center of Applied Energy Research (ZAE) in Bavaria, Germany. Heat losses test results reported by Beikircher et al. 2014 [26] showed that the tank had a cooling rate of $0.23 \mathrm{~K} /$ day. Different materials to be used as vacuum insulation in a double walled water storage tank were investigated by Lang et al. [27]. The study concluded that a mixture of expanded perlite $(70 \%)$ and fumed silica $(30 \%)$ had the best results at vacuum pressures between 1 and 10 mbar. The mixture was tested in a real water tank of $12 \mathrm{~m}^{3}$ built by Sirch TankbauTankservice-Speicherbau GmbH. The experimental test showed an overall temperature drop of around $0.25 \mathrm{~K} /$ day. The heat losses were mostly attributed to the thermal bridges at the bottom of the tank due to the TES support. To the best of the authors' knowledge, the experimental studies published so far only show the performance of vacuum water tanks with a useful volume higher than $10 \mathrm{~m}^{3}$. At present, there are no studies in the literature that report the efficiency of small-size water tanks using vacuum insulation for small building applications such as a single-family house.

To fill this literature gap, this paper shows the heat transfer performance of a water tank of a volume of $0.535 \mathrm{~m}^{3}$ with a vacuum insulated double wall suitable for space heating (SH) and domestic hot water (DHW) supply for domestic applications. The tank was included and tested in the framework of the EU-funded project SWS-HEATING (GA 764025) to be coupled with a novel seasonal TES based on selective water sorbent materials to maximise the solar fraction. The study shows the experimental results of heat loss tests to evaluate the behaviour of the vacuum water tank, considering also the effect of stratification on the heat losses. In the literature, different methods were employed to evaluate the heat losses of solar water tanks. Cruickshank et al. [28] evaluated the heat loss coefficient through a "cool-down test". The tests were conducted in a $0.270 \mathrm{~m}^{3}$ electric water-storage tank with fibre-glass insulation. During such experiments, the water tank was preheated to $54{ }^{\circ} \mathrm{C}$ and the temperature was recorded over a period of $48 \mathrm{~h}$. Another way to estimate the heat losses in a water tank is to charge the tank over a long period with a gradual temperature increase, reaching a steady state value of heat losses, which are then evaluated from the heating power supplied to the tank and the ambient temperature, as reported by Deng et al. [29].

\section{Materials and Methods}

\subsection{Experimental Methodology}

\subsubsection{Experimental Set-Up}

The tests were carried out using a specific test rig built in the GREiA research group of the University of Lleida (Figure 2). The test rig consists of a 200 litres commercial buffer tank with a built-in $9 \mathrm{~kW}$ electric heater and a monoblock pump (model OE-IP22- 
12037) controlled by an Invertek optidrive E3 IP20 variable speed drive. To measure the ambient temperature and the external surface temperature of the tank, $3 \mathrm{Pt}-100$ class A IEC 60751 standard type temperature sensors (accuracy $0.15 \pm 0.002 * t$ ) were implemented. All monitoring variables were recorded through a data acquisition system (STEP DL-01 data logger) connected to a computer equipped with Indusoft SCADA software. The measurement interval was $1 \mathrm{~s}$ and the recording interval (time step) was set at $10 \mathrm{~s}$.

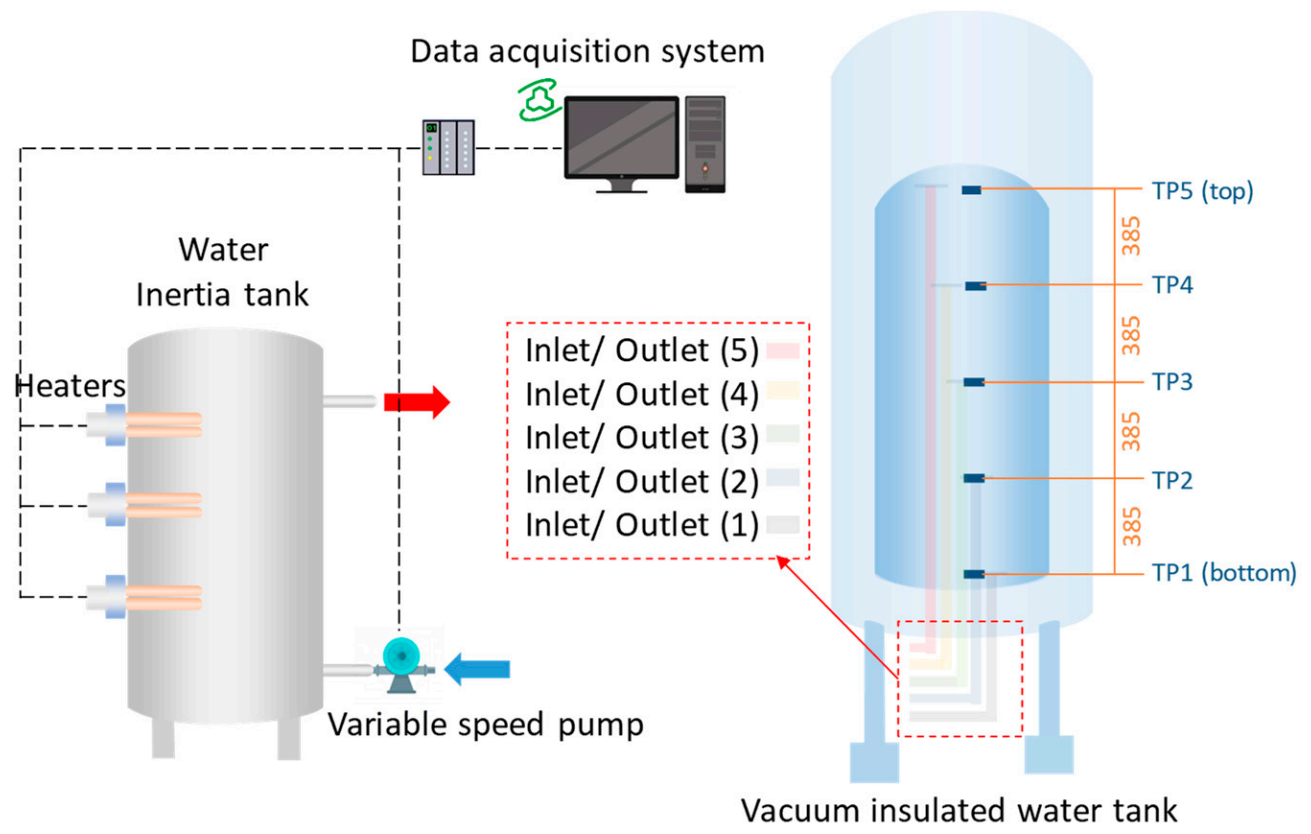

Figure 2. Schematic view of the experimental set-up used to perform the experimentation.

\subsubsection{Characteristics of the Water Tank}

The storage tank tested in this study is a vacuum insulated water tank built by Sirch Tankbau-Tankservice-Speicherbau GmbH [30]. A general schematic of the tank is shown in Figure 3. The tank contains 5 ports evenly distributed over the height of the tank. It is made of steel S235JRG2, has a total height of $2.5 \mathrm{~m}$ and an external diameter of $1 \mathrm{~m}$, with a total capacity of $0.535 \mathrm{~m}^{3}$. The water tank was built with a vacuum insulated double wall evacuated and filled with thermal radiation absorber. The vacuum insulation with a thickness of $0.17 \mathrm{~m}$ is not removable and, according to the manufacturer, it is characterised by an absolute pressure below $10 \mathrm{mbar}$ and thermal conductivity of $0.008 \mathrm{~W} / \mathrm{m} \cdot \mathrm{K}$. In order to analyse the stratification and heat losses inside the tank, the manufacturer was asked to place $5 \mathrm{Pt}-100$ class A IEC 60751 standard type (accuracy $0.15 \pm 0.002 * \mathrm{t}$ ) temperature sensors inside the tank. The sensors were placed at the central axis of the tank vertically distributed with similar spacing between them and the same height of each tank port, as shown in Figure 4. At least three repetitions of each test were performed to ensure repeatability.

\subsubsection{Heat Losses Test}

In this study, heat losses were evaluated through a "cool-down test", preheating the tank at different temperature levels and recording the temperature inside the tank, in the external surface of the tank, and the ambient temperature for $48 \mathrm{~h}$. Mainly, two different heat losses tests were performed with two different boundary conditions:

- $\quad$ Test A: water tank is preheated at a uniform temperature of $65^{\circ} \mathrm{C}$;

- $\quad$ Test B: water tank is preheated at $45^{\circ} \mathrm{C}$ at the bottom and middle layers, and at $65^{\circ} \mathrm{C}$ at the top. 

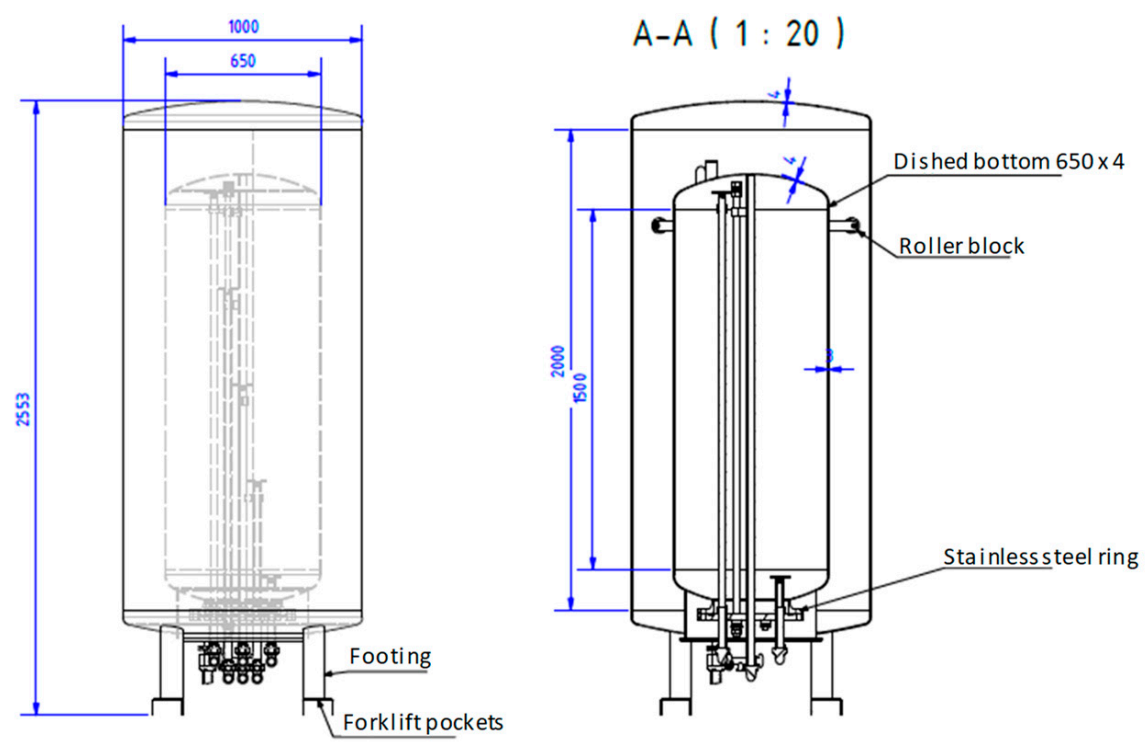

Figure 3. Schematic of the $0.535 \mathrm{~m}^{3}$ water tank built by Sirch Tankbau-Tankservice Speicherbau $\mathrm{GmbH}$ [30]. All measurements are presented in millimeters.

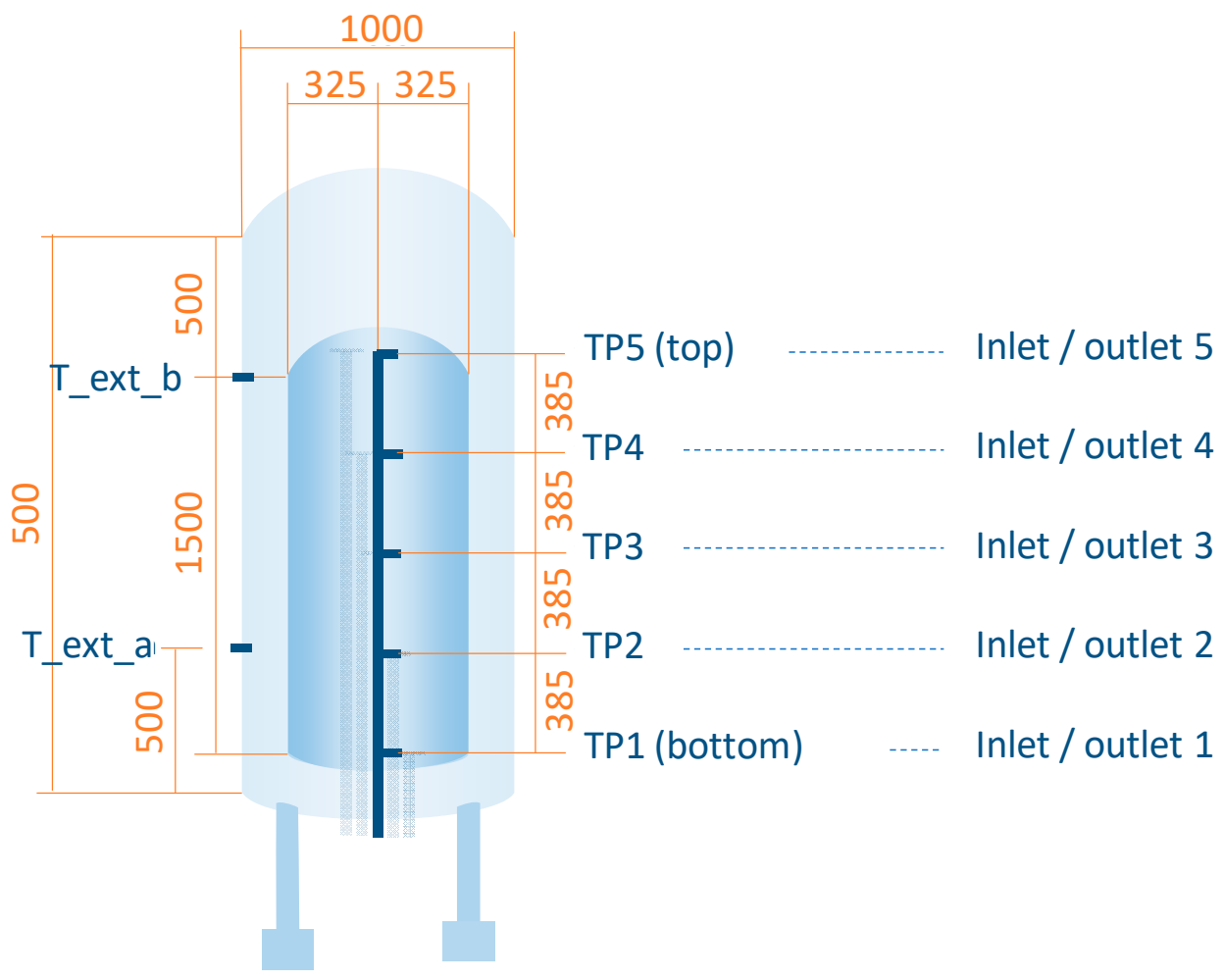

Figure 4. Schematic of the connections and sensors inserted inside the water tank (TP1, TP2, TP3, TP4, TP5), and on the outer surface (T_ext_a, and T_ext_b). All measurements are presented in millimetres.

To perform test $\mathrm{A}$, water at $65^{\circ} \mathrm{C}$ was circulated between the buffer tank and connections 1 and 5 of the vacuum water tank (Figure 2) until all sensors inside the tank (TP1 to TP5) were at $(65 \pm 2){ }^{\circ} \mathrm{C}$. Then all connections to the vacuum water tank were closed, and temperatures inside the tank were recorded for $48 \mathrm{~h}$.

To perform test $\mathrm{B}$, water at $45^{\circ} \mathrm{C}$ was circulated between the buffer tank and connections 1 and 5 of the vacuum water tank (Figure 2) until all sensors inside the tank (TP1 to TP5) were at $(45 \pm 2){ }^{\circ} \mathrm{C}$. Next, water at $65{ }^{\circ} \mathrm{C}$ was circulated between the buffer tank and connections 4 and 5 of the vacuum water tank until the sensors TP4 and TP5 inside the 
tank were at $(65 \pm 2){ }^{\circ} \mathrm{C}$. Then all connections to the vacuum water tank were closed, and temperatures inside the tank were recorded for $48 \mathrm{~h}$.

\subsubsection{Repeatability of Results}

Each test was repeated three times to demonstrate the repeatability of the methodology and the experimental results. Figure 5 presents the water temperature profiles of test $\mathrm{A}$ at the five temperature levels presented also in Figure 5. Results from the repeatability tests show that the methodology adopted for the present experimentation produced repeatable values with a maximum standard deviation of $0.189^{\circ} \mathrm{C}$ in the sensor TP1 over the first 5 min of experiments, and a mean standard deviation of $0.036{ }^{\circ} \mathrm{C}$ between all sensors throughout the experiment. Results for test $\mathrm{B}$ showed similar differences and are therefore not presented.
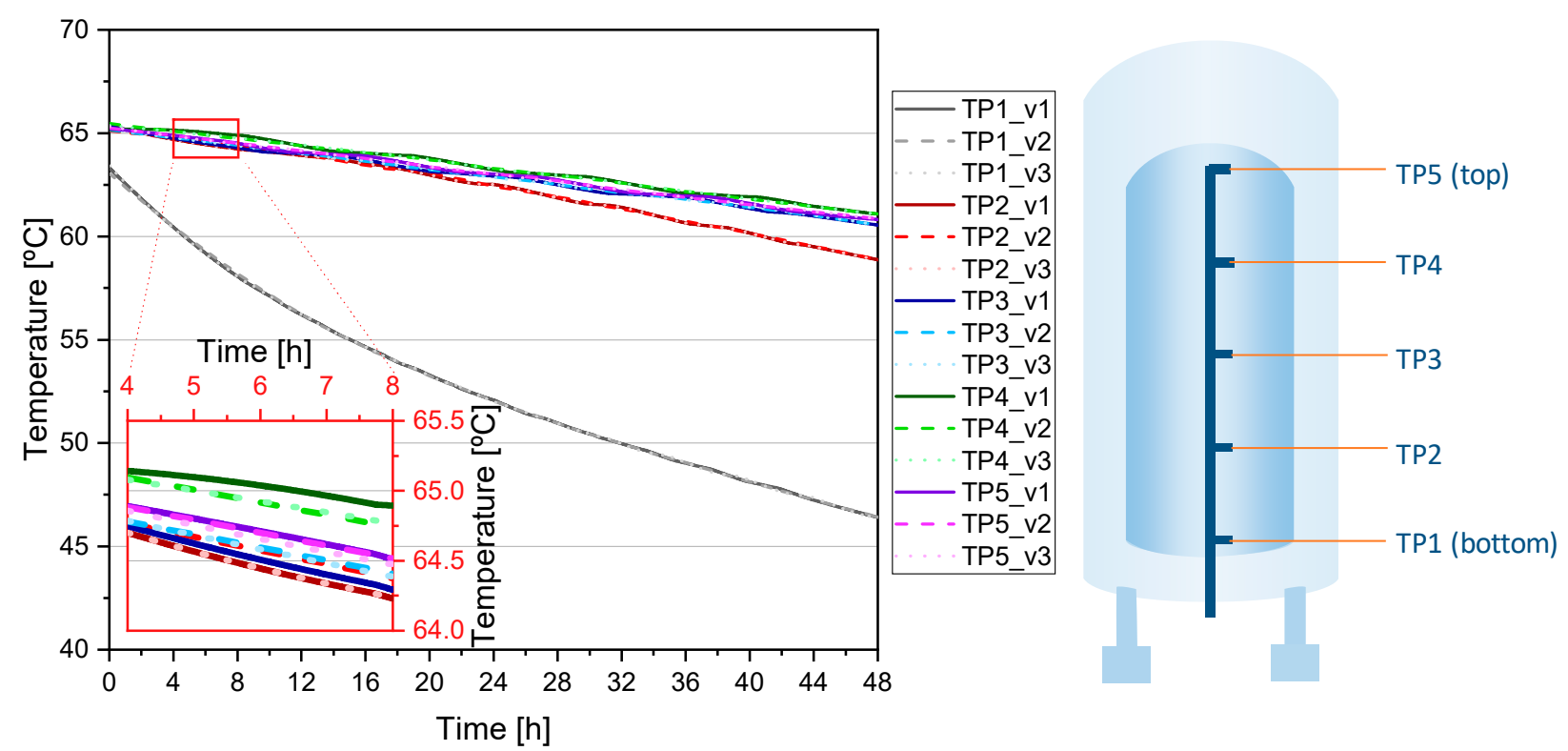

Figure 5. Repeatability tests for the case study A.

\subsection{Theoretical Methodology}

The heat losses $(\mathrm{kWh})$ were calculated from the experimental data considering the variation of the temperature inside the tank at different heights. To calculate total losses, the tank was divided into five different water volumes corresponding to the position of the sensors, as shown in Figure 6. Therefore, the total heat losses were calculated as the sum of the heat loss by each element $i$ with mass of water $m_{i}$, as shown in Equation (1):

$$
Q_{\text {loss }}=\sum_{i=1}^{n} m_{i} \times c_{p} \times \Delta T
$$

where $\Delta T$ is the temperature variation of each layer during the heat losses test.

Then, the data obtained from the heat losses test can be used to estimate the U-value and the UA-value of the vacuum water tank.

In this case, for the calculation of the U-value, heat conduction between the adjacent nodes is assumed negligible. For each volume " $i$ ", the UA-value can be calculated from the heat losses as shown in Equation (2):

$$
U A_{i}=\frac{Q_{\text {loss }, i}}{T_{\text {ave }, i}-T_{\text {ave }, a m b}}
$$


where $Q_{\text {loss }, i}$ is the heat loss $(\mathrm{kW})$ calculated from the experimental data of the volume $i$ characterised by the average temperature value $\left(T_{a v e, i}\right)$, and the ambient temperature measured from the test $\left(T_{\text {ave, amb }}\right)$,

The U-value can be derived from the UA-value as:

$$
U=\frac{U A_{i}}{A_{i}}
$$
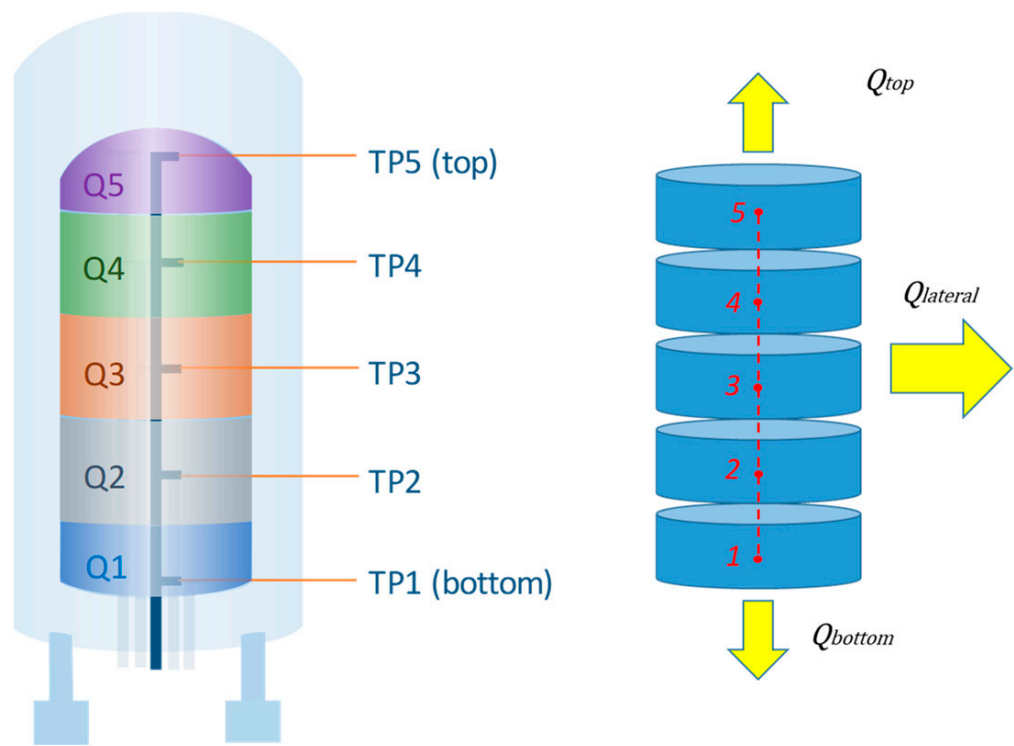

Figure 6. Volume discretisation of the tank for the U-value calculation.

According to the design of the tank, three different U-values can be calculated for three different surfaces: bottom base, lateral (side) surface, and top base.

The U-value for the lateral surface can be obtained from any of the middle layers (T2, T3, and T4) using Equation (4):

$$
U_{\text {lateral }}=\frac{U A_{i, \text { lateral }}}{A_{i, \text { lateral }}}
$$

where $U A_{i, \text { lateral }}$ is derived from Equation (3) because, for a middle layer, heat transfer only takes place through the lateral surface, and $A_{i, \text { lateral }}$ is the lateral surface area of the middle layer " $i$ ".

For the bottom layer, the total UA-value is the sum of the UA-value of the bottom base surface and the UA-value of the lateral surface, as shown in Equation (5):

$$
U A_{\text {bottom,tot }}=U A_{\text {bottom,base }}+U A_{\text {bottom,lateral }}
$$

where $U A_{\text {bottom,tot }}$ is derived from Equation (3) and $U A_{\text {bottom,lateral }}$ is obtained by multiplying the value of $U_{\text {lateral }}$ calculated in Equation (4) by the lateral surface area of the bottom layer $\left(A_{\text {bottom,lateral }}\right)$.

Therefore, the U-value of the bottom base surface can be calculated as shown in Equation (6):

$$
U_{\text {bottom,base }}=\frac{U A_{\text {bottom, base }}}{A_{\text {bottom,base }}}=\frac{U A_{\text {bottom,tot }}-U A_{\text {bottom, lateral }}}{A_{\text {bottom,base }}}
$$

Equations similar to (5) and (6) can be applied to calculate the UA-value of the top base surface of the tank and derive the U-value of the top base surface, $U_{\text {top,base }}$. 


\section{Results}

\subsection{Heat Losses Test Results}

\subsubsection{Test A}

Figure 7 shows the variation of the temperature inside the tank previously charged uniformly at $65{ }^{\circ} \mathrm{C}$ and left at ambient temperature for $48 \mathrm{~h}$. The figure also reports the variation of the ambient temperature $\left(\mathrm{T}_{\mathrm{amb}}\right)$ and the external temperature of the tank measured by means of two sensors placed on the surface ( $T_{-}$ext_a, $T_{-}$ext_b $)$. During the test, the ambient temperature and the external surface temperature of the tank were almost constant. From Figure 7, one can see that the temperature variation at the bottom of the tank (TP1) had the highest cooling rate, decreasing to $46^{\circ} \mathrm{C}$ after $48 \mathrm{~h}$. On the other hand, the temperature of the top and middle layers (TP2, TP3, TP4, TP5) experienced a small variation during the test, decreasing to $60^{\circ} \mathrm{C}$ after $48 \mathrm{~h}$.
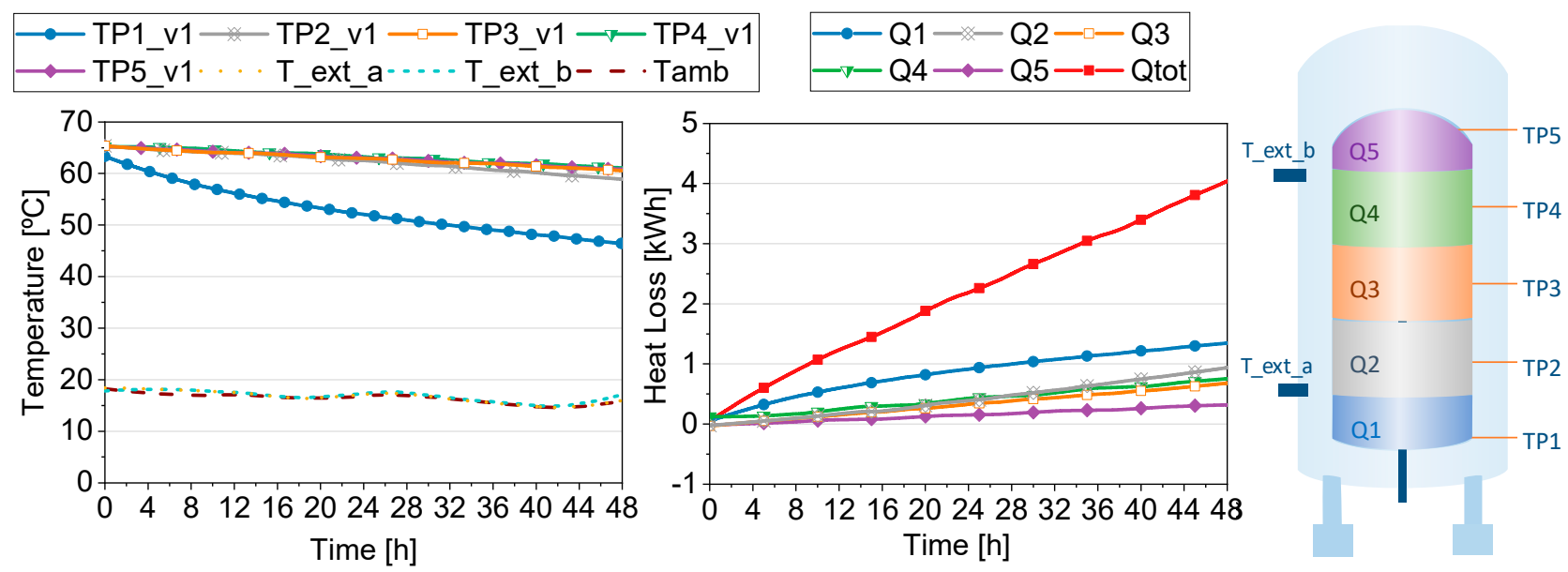

Figure 7. Temperature profiles (left) and calculated heat losses (right) for test A. Tamb represents the ambient temperature and Qtot is the sum of heat losses from Q1 to Q5.

The calculated energy losses are shown in Figure 7 right. The results show that a total energy amount of $4 \mathrm{kWh}$ was lost during the test, mostly affected by the heat losses at the bottom layer of the tank (Q1).

\subsubsection{Test B}

The temperature profiles measured during the heat losses test of the water tank charged with a stratified profile $\left(45^{\circ} \mathrm{C}\right.$ at the bottom and middle layers 2 and 3 , and $65{ }^{\circ} \mathrm{C}$ at the top layers 4 and 5) are shown in Figure 8 left. From the results, it is possible to notice that in the middle of the tank (TP3) the temperature increases over time due to the conduction between the water volumes at different temperatures. In this case, the temperature of the top layers (TP4 and TP5) drops faster than the bottom of the tank. Indeed, due to heat transfer between layers, the temperature of the top levels drops below $60{ }^{\circ} \mathrm{C}$ after $48 \mathrm{~h}$, resulting in higher energy losses compared to the previous case shown in Figure 8. The energy losses evaluated from the test are shown in Figure 8 right.

In this case, the total energy loss is almost half compared to the previous case (Test A) with the initial tank uniformly charged at $65^{\circ} \mathrm{C}(2.1 \mathrm{kWh}$ compared to $4 \mathrm{kWh})$. Furthermore, Figure 8 right shows that the part of the tank with the highest temperature drop are the top layers of the tank (TP4, TP5) and the bottom layer (TP1). The temperature drop at the top part are probably mostly due to heat transfer towards the middle part of the tank, while the temperature drop at the bottom is mainly due to heat losses to the ambient.

However, compared to the previous case with the water tank fully charged at $65{ }^{\circ} \mathrm{C}$, the final value of heat losses at the bottom layer is lower $(0.7 \mathrm{kWh})$ due to the lower temperature difference between the water inside the tank and the ambient that results in a lower heat transfer rate, thus reducing the heat losses. On the other hand, Figure 8 right 
shows that in the middle layer (Q3) the heat losses has a negative value (that in this case is a heat gain) due to the increase in temperature (TP3) shown in Figure 8 left.

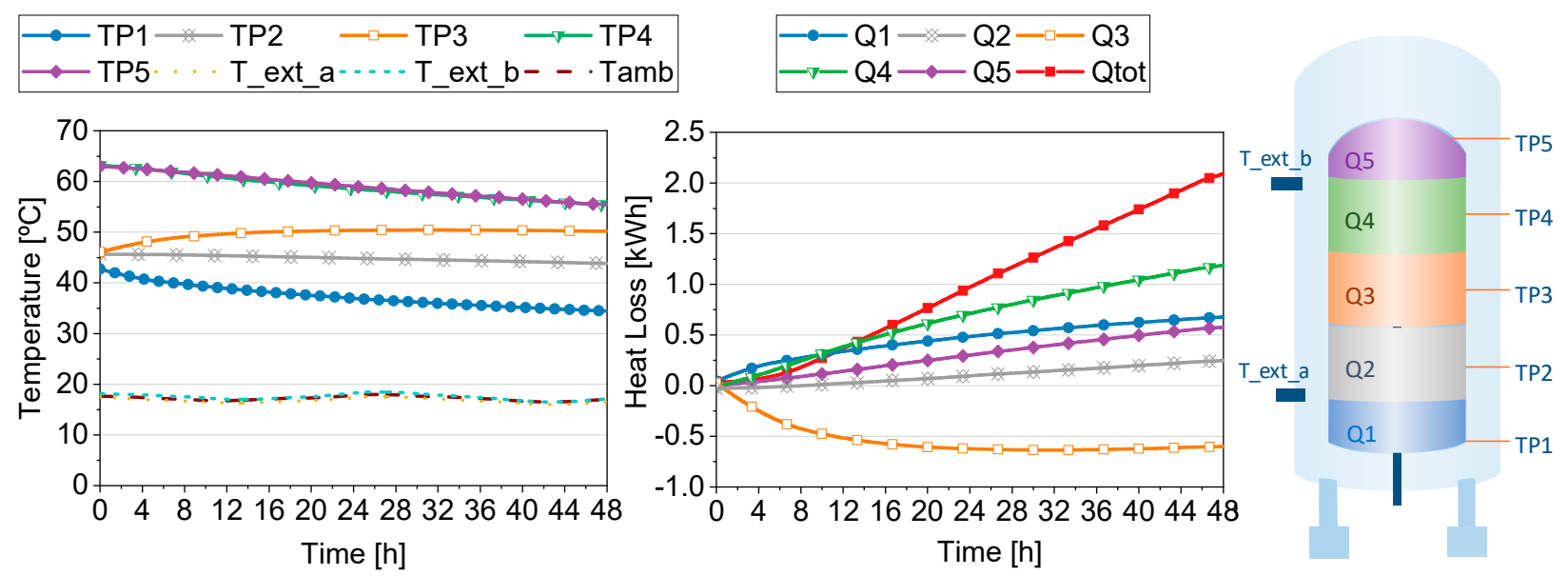

Figure 8. Temperature profiles (left) and calculated heat losses (right) for test B. Tamb represents the ambient temperature and Qtot is the sum of heat losses from Q1 to Q5.

\subsection{U-Value Calculation}

The results of the heat loss tests were used to obtain a first estimation of the U-value of the water tank tested in this study. To reduce the effect of the conduction between the layers inside the tank, the results of Test A (preheating at a uniform temperature of $65{ }^{\circ} \mathrm{C}$ ) were used. The U-values calculated for the different sections of the tank are presented in Table 1. To quantitatively evaluate the values obtained from the calculation, the U-values were compared with the one obtained from the literature. In particular, Table 1 shows the comparison of the U-value with the one obtained from Cruickshank et al. [28] calculated for a commercial $0.270 \mathrm{~m}^{3}$ standard water storage tank insulated with $0.047 \mathrm{~m}$ of fibre-glass $(\mathrm{k}=0.036 \mathrm{~W} /(\mathrm{m} \cdot \mathrm{K}))$.

Table 1. U-values calculated for this study and comparison with the literature.

\begin{tabular}{cccccc}
\hline & \multirow{2}{*}{ Tank Volume $\left(\mathbf{m}^{\mathbf{3}}\right)$} & Insulation Type & \multicolumn{3}{c}{ U-Value $\left(\mathbf{W} /\left(\mathbf{m}^{2} \cdot \mathbf{K}\right)\right)$} \\
\cline { 3 - 6 } & & & Top & Lateral & Bottom \\
\hline This study & 0.535 & Double wall with vacuum & 0.32 & 0.38 & 2.00 \\
Cruickshank et al. [28] & 0.270 & Fibre-glass & 0.66 & 1.05 & 2.54 \\
\hline
\end{tabular}

Table 1 shows that the U-value of the bottom surface of the vacuum tank is the highest compared to the one estimated for the lateral surface due to the high energy loss observed at the bottom of the tank (Figure 6). This value is similar to the one of a standard electric water tank due to the absence of vacuum insulation in the bottom part of the tank. However, the U-value of the lateral and the top surface, calculated for the vacuum water tank tested in this study, are significantly reduced compared to conventional insulation due to the minor energy losses at the top and middle layers of the tank.

\section{Discussion and Conclusions}

The reduction of heat losses of thermal energy storage is important to maintain high efficiency and to increase the solar fraction of solar heating systems. However, the enhancement of insulation quality is often overlooked, still representing a research gap in the literature. Reducing the heat losses using conventional materials with high thermal conductivity could lead to an increase of the dimension of the storage systems indirectly affecting the cost of the storage itself. Vacuum insulation is one technique proposed to effectively reduce heat losses in large-size water tanks. In this study, heat loss tests were 
carried out to evaluate the performance of a $0.535 \mathrm{~m}^{3}$ water tank built with a vacuum insulated double wall for residential building applications. In particular, two different tests were carried out, preheating the tank at different temperature levels and recording the temperature without supplying heat to the tank for $48 \mathrm{~h}$.

The results showed that the technique of vacuum insulation can effectively reduce the heat losses in small-size water tanks for domestic applications. Indeed, compared to a standard water tank, the U-value can be significantly lower, allowing to maintain the water at high temperature inside the tank. However, the critical part of the design of those tanks is the bottom side that is usually used to place the support parts and the piping of the tank, which act as thermal bridges to the ambient. Furthermore, due to the lack of insulation, the bottom surface is the most exposed to the outside temperature thus reducing the effectiveness of the insulation and enabling significant heat losses.

The two different tests carried out in this study showed that the heat loss rates depends on the average water temperature inside the tank. Indeed, a tank filled with water at lower temperature due to stratification has a considerably lower heat losses rate due to the smaller temperature difference with the ambient, which is especially significant at the bottom surface where most of heat losses occur.

Although vacuum insulation was proven to have benefits in reducing heat losses, it has to be considered that a water tank with this type of insulation has a much higher cost compared to a standard water tank. Therefore, in order to prove the real benefit of using vacuum insulation in solar heating systems, further research needs to be done in future studies, including detailed cost-benefit analysis related to the efficiency improvement in a generic heating system.

Author Contributions: Conceptualisation, D.V., E.B. and L.F.C.; methodology, D.V., E.B. and G.Z.; formal analysis, D.V., E.B. and G.Z.; investigation, D.V., A.C. and E.B.; resources, L.F.C.; data curation, L.F.C.; writing-original draft preparation, D.V. and E.B.; writing—review and editing, A.C., G.Z., B.D. and L.F.C.; visualisation, D.V. and E.B.; supervision, L.F.C.; project administration, L.F.C.; funding acquisition, L.F.C. All authors have read and agreed to the published version of the manuscript.

Funding: This project has received funding from the European Union's Horizon 2020 research and innovation programme under grant agreement No 764025 (SWS-HEATING). This work was partially funded by the Ministerio de Ciencia, Innovación y Universidades de España (RTI2018-093849-B-C31$\mathrm{MCIU} / \mathrm{AEI} / \mathrm{FEDER}, \mathrm{UE}$ ) and by the Ministerio de Ciencia, Innovación y Universidades-Agencia Estatal de Investigación (AEI) (RED2018-102431-T).

Institutional Review Board Statement: Not applicable.

Informed Consent Statement: Not applicable.

Data Availability Statement: The data presented in this study are available on request from the corresponding author.

Acknowledgments: The authors would like to thank the Catalan Government for the quality accreditation given to their research group GREiA (2017 SGR 1537). GREiA is a certified agent TECNIO in the category of technology developers from the Government of Catalonia. This work is partially supported by ICREA under the ICREA Academia programme. Alicia Crespo would like to acknowledge the financial support of the FI-SDUR grant from the AGAUR of the Generalitat de Catalunya and Secretaria d'Universitats i Recerca del Departament d'Empresa i Coneixement de la Generalitat de Catalunya.

Conflicts of Interest: The authors declare no conflict of interest.

\section{References}

1. Navarro, L.; de Gracia, A.; Colclough, S.; Browne, M.; McCormack, S.J.; Griffiths, P.; Cabeza, L.F. Thermal energy storage in building integrated thermal systems: A review. Part 1. active storage systems. Renew. Energy 2016, 88, 526-547. [CrossRef]

2. Arce, P.; Medrano, M.; Gil, A.; Oró, E.; Cabeza, L.F. Overview of thermal energy storage (TES) potential energy savings and climate change mitigation in Spain and Europe. Appl. Energy 2011, 88, 2764-2774. [CrossRef]

3. Borri, E.; Tafone, A.; Zsembinszki, G.; Comodi, G.; Romagnoli, A.; Cabeza, L.F. Recent Trends on Liquid Air Energy Storage: A Bibliometric Analysis. Appl. Sci. 2020, 10, 2773. [CrossRef] 
4. Borri, E.; Zsembinszki, G.; Cabeza, L.F. Recent developments of thermal energy storage applications in the built environment: A bibliometric analysis and systematic review. Appl. Therm. Eng. 2021, 189, 116666. [CrossRef]

5. Cabeza, L.F.; Frazzica, A.; Chàfer, M.; Vérez, D.; Palomba, V. Research trends and perspectives of thermal management of electric batteries: Bibliometric analysis. J. Energy Storage 2020, 32, 101976. [CrossRef]

6. van Eck, N.J.; Waltman, L. Software survey: VOSviewer, a computer program for bibliometric mapping. Scientometrics 2010, 84, 523-538. [CrossRef] [PubMed]

7. Kurşun, B.; Ökten, K. Effect of rectangular hot water tank position and aspect ratio on thermal stratification enhancement. Renew. Energy 2018, 116, 639-646. [CrossRef]

8. Fan, J.; Furbo, S. Thermal stratification in a hot water tank established by heat loss from the tank. Sol. Energy 2012, 86, 3460-3469. [CrossRef]

9. Han, Y.M.; Wang, R.Z.; Dai, Y.J. Thermal stratification within the water tank. Renew. Sustain. Energy Rev. 2009, 13, 1014-1026. [CrossRef]

10. Dragsted, J.; Furbo, S.; Dannemand, M.; Bava, F. Thermal stratification built up in hot water tank with different inlet stratifiers. Sol. Energy 2017, 147, 414-425. [CrossRef]

11. Chandra, Y.P.; Matuska, T. Stratification analysis of domestic hot water storage tanks: A comprehensive review. Energy Build. 2019, 187, 110-131. [CrossRef]

12. Castell, A.; Medrano, M.; Solé, C.; Cabeza, L.F. Dimensionless numbers used to characterize strati fi cation in water tanks for discharging at low fl ow rates. Renew. Energy 2010, 35, 2192-2199. [CrossRef]

13. Mazman, M.; Cabeza, L.F.; Mehling, H.; Nogues, M.; Evliya, H.; Paksoy, H.Ö. Utilization of phase change materials in solar domestic hot water systems. Renew. Energy 2009, 34, 1639-1643. [CrossRef]

14. Mehling, H.; Cabeza, L.F.; Hippeli, S.; Hiebler, S. PCM-module to improve hot water heat stores with stratification. Renew. Energy 2003, 28, 699-711. [CrossRef]

15. Klein, K.; Herkel, S.; Henning, H.-M.; Felsmann, C. Load shifting using the heating and cooling system of an office building: Quantitative potential evaluation for different flexibility and storage options. Appl. Energy 2017, 203, 917-937. [CrossRef]

16. Yan, C.; Xue, X.; Wang, S.; Cui, B. A novel air-conditioning system for proactive power demand response to smart grid. Energy Convers. Manag. 2015, 102, 239-246. [CrossRef]

17. Comodi, G.; Giantomassi, A.; Severini, M.; Squartini, S.; Ferracuti, F.; Fonti, A.; Nardi Cesarini, D.; Morodo, M.; Polonara, F. Multi-apartment residential microgrid with electrical and thermal storage devices: Experimental analysis and simulation of energy management strategies. Appl. Energy 2015, 137, 854-866. [CrossRef]

18. Sirch Tankbau-Tankservice-Speicherbau GmbH. Available online: https://www.sirch.com/ (accessed on 20 April 2021).

19. Villasmil, W.; Fischer, L.J.; Worlitschek, J. A review and evaluation of thermal insulation materials and methods for thermal energy storage systems. Renew. Sustain. Energy Rev. 2019, 103, 71-84. [CrossRef]

20. Fuchs, B.; Hofbeck, K.; Faulstich, M. Vacuum insulation panels-A promising solution for high insulated tanks. Energy Procedia 2012, 30, 424-427. [CrossRef]

21. Kang, M.; Kim, J.; You, H.; Chang, D. Experimental investigation of thermal stratification in cryogenic tanks. Exp. Therm. Fluid Sci. 2018, 96, 371-382. [CrossRef]

22. Edward, L.; Filip, L. Influence of vacuum level on insulation thermal performance for LNG cryogenic road tankers. MATEC Web Conf. 2018, 240, 1019. [CrossRef]

23. Kalder, J.; Annuk, A.; Allik, A.; Kokin, E. Increasing solar energy usage for dwelling heating, using solar collectors and medium sized vacuum insulated storage tank. Energies 2018, 11, 1832. [CrossRef]

24. Fantucci, S.; Lorenzati, A.; Kazas, G.; Levchenko, D.; Serale, G. Thermal energy storage with super insulating materials: A parametrical analysis. Energy Procedia 2015, 78, 441-446. [CrossRef]

25. Fuchs, B.; Hofbeck, K. First experience in vacuum insulated hot water storage with $100 \mathrm{~m}^{3}$. Energy Procedia 2014, 57, 2390-2398. [CrossRef]

26. Beikircher, T.; Buttinger, F.; Demharter, M. Super-insulated long-term hot water storage. Sol. World Congr. 2011, 6, 4893-4898.

27. Lang, S.; Gerschitzka, M.; Bauer, D.; Drück, H. Thermal conductivity of vacuum insulation materials for thermal energy stores in solar thermal systems. Energy Procedia 2016, 91, 172-181. [CrossRef]

28. Cruickshank, C.A.; Harrison, S.J. Heat loss characteristics for a typical solar domestic hot water storage. Energy Build. 2010, 42, 1703-1710. [CrossRef]

29. Deng, J.; Furbo, S.; Kong, W.; Fan, J. Thermal performance assessment and improvement of a solar domestic hot water tank with PCM in the mantle. Energy Build. 2018, 172, 10-21. [CrossRef]

30. Sirch Tankbau-Tankservice-Speicherbau GmbH. Available online: https:/ / pufferspeicher-sirch.de/ start/ (accessed on 26 January 2021). 